\title{
OPINIE
}

\section{De ILO en het Nederlandse arbeidsrecht ${ }^{*}$}

\author{
Paul F. van der Heijden
}

\section{Inleiding}

Nederland is vanaf het eerste begin van de International Labour Organization (ILO) in 1919 lid geweest van deze tripartite wereldomspannende organisatie, die zich met 'werk' bezighoudt. ${ }^{1}$ De ILO is sinds 1945 onderdeel van de 'VN-familie', net als de World Health Organization (WHO; gezondheid), de Food and Agriculture Organization (FAO; voedsel), de World Bank (krediet) en tien anderen. Dat betekent dat Nederland binnenkort een eeuw lidmaatschap kan vieren, nu de ILO in 2019 haar eeuwfeest viert.

Is er genoeg aanleiding voor feest? Heeft Nederland zich een beetje gedragen als lid door zich bijvoorbeeld aan de door het lidmaatschap aangegane verplichtingen te houden?

Nederland betaalde trouw al die jaren de contributie van het lidmaatschap en zendt ook netjes iedere keer in juni een tripartite delegatie naar Genève voor deelname aan de International Labour Conference (ILC), waar verdragen en aanbevelingen worden gemaakt. Meestal gaat ook de dienstdoende minister van Sociale Zaken en Werkgelegenheid (SZW) in die periode naar Genève om de ILC toe te spreken. Ook doet Nederland van tijd tot tijd wat extra's door speciale programma's geldelijk te steunen, zoals bijvoorbeeld het programma om kinderarbeid te bestrijden in het International Program for the Elimination of Child Labour (IPEC). ${ }^{2}$ Maar er waren ook wel 'aanvaringen', zoals bijvoorbeeld in de vorige eeuw aangaande geleide loonpolitiek en de lonen in de semipublieke sector. Ook meer recent 'bemoeide' de ILO zich met Nederland, nu over de sterkte van de Arbeidsinspectie.

In deze bijdrage wil ik een aantal aspecten van de Nederlandse deelname aan de ILO belichten. Heeft de ILO invloed (gehad) op ons arbeidsrecht? En zo ja, welke? Heeft Nederland zich opgesteld als een actief en betrokken lid? Heeft Nederland de ILO iets gebracht en heeft de ILO Nederland iets gebracht?

* De auteur dankt student-assistent Jan Herfkens voor zijn onmisbare hulp bij het schrijven van deze bijdrage.

1 Ik gebruik in deze bijdrage de ingeburgerde afkorting ILO in plaats van de minder bekende Nederlandse afkorting IAO (Internationale Arbeidsorganisatie), die overigens in Vlaanderen weer wel gebruikt en gekend is.

2 www.ilo.org/ipec/lang--en/index.htm. 


\section{Ratificaties van ILO-verdragen en doorwerking in Nederland ${ }^{3}$}

De ILO is een internationale 'globale' organisatie die zich bezighoudt met een aantal taken op het gebied van 'werk'. Vrijwel alle landen ter wereld zijn er lid van. Ze verzamelt 'global data' over kinderarbeid en dwangarbeid, over werkgelegenheid en werkloosheid, over economie en werk, over veiligheid en gezondheid op het werk, over sociale zekerheid en over nog veel meer. Daarnaast ontwikkelt ze beleid over deze onderwerpen, dikwijls door eerst verdragen en aanbevelingen vast te stellen, die vervolgens kunnen worden geratificeerd en geïmplementeerd in de rechtsorde van de lidstaten. De ILO heeft op die manier met de tot stand gebrachte verdragen in de loop der jaren een internationaal wetboek van de arbeid, een 'International Labour Code' gecreëerd. Daarnaast houdt ze ook toezicht op de naleving van geratificeerde verdragen via een ingewikkeld, maar toch tot 2012 redelijk succesvol supervisiesysteem. ${ }^{4}$

Waar staat de ILO voor? Het gaat de organisatie om niets minder dan sociale rechtvaardigheid en menselijke waardigheid op wereldschaal. Haar hele bestaan staat in het teken van het bestrijden van ongelijkheid en onveiligheid op de werkvloer, van het tegengaan van concurrentie op arbeidsvoorwaarden, van het voorkómen van een 'race to the bottom', en sinds 1999 van het bevorderen van 'decent work', dat met 'fatsoenlijk werk' maar gedeeltelijk valt te vertalen. De Decent Work Agenda van de ILO richt zich op het wereldwijd doen aanvaarden en implementeren van de fundamentele arbeidsrechten (vakbondsvrijheid/collectieve onderhandelingsvrijheid, verbod van kinderarbeid, dwangarbeid en discriminatie op de werkplek), van het belang van de sociale dialoog, van een veilige en gezonde werkomgeving, en van een bodem voor bestaanszekerheid in de vorm van sociale zekerheid.

De ILO heeft sinds haar ontstaan in 1919 veel verdragen vastgesteld, in totaal 189 , om de gestelde doelen te bereiken. Daarvan is uiteraard een aantal verouderd, die buiten werking worden of zijn gesteld.

De ILO is al jaren doende de stofkam door de verdragen te halen om te bezien welke precies nog van betekenis zijn in de 21ste eeuw, en welke niet. ${ }^{5}$

De Nederlandse regering geeft jaarlijks aan de delegatie die de ILC bezoekt (de jaarvergadering van de ILO) instructies mee over hoe te handelen en heeft ook algemene criteria geformuleerd ter zake van de vraag of een onderwerp voor regulering door de ILO in aanmerking komt. De ILO-verdragen moeten een bijdrage leveren aan een internationaal 'level playing field', zodat concurrentie op minimumnormen niet meer aan de orde kan zijn. De verdragen moeten ook niet (te) gedetailleerd zijn, maar vooral principes vastleggen en detaillering overlaten aan

3 Ik vertaal in deze bijdrage de 'Conventions' als 'verdragen', maar laat wel de in 'ILO-speak' gebruikelijke afkorting ' $C$ ' gevolgd door het nummer van het verdrag in stand.

4 Zie hierover in het kort Rules of the Game (ILO): www.ilo.org/global/standards/informationresources-and-publications/publications/WCMS_318141/lang--en/index.htm. www.ilo.org/dyn/normlex/en/f?p=NORMLEXPUB:12000:0::NO. 
de nationale wetgeving. Ook moet niet worden ingezet op méér verdragen, maar op modernisering van bestaande verdragen. ${ }^{6}$

Nederland heeft 106 ILO-verdragen geratificeerd en staat daarmee op de 7de plaats als het gaat om het totaal aantal geratificeerde verdragen. Het kan beter: Spanje ratificeerde 133 verdragen, Frankrijk 127, Italië 113, Noorwegen 110 en België 108. Het kan ook veel slechter: de VS ratificeerde 14 verdragen, China 26 en India 47; deze drie ILO-lidstaten alleen zijn al goed voor bijna de helft van de wereldbevolking, namelijk 3 miljard van de ruim 7,5 miljard. ${ }^{7}$

Ratificatie betekent soms dat de nationale wetgeving dan wel de praktijk over het betreffende onderwerp moet worden aangepast, en dat is dikwijls een reden om niet tot ratificatie over te gaan. Ook kan het zijn dat de minister van SZW van oordeel is dat de betreffende materie in Nederland al veel beter geregeld is en ratificatie daar alleen maar complexiteit aan toevoegt. Van de verdragen van de laatste twintig jaar ratificeerde Nederland bijvoorbeeld wel die over Uitzendwerk (C 181), Moederschapsbescherming (C 183), Parttime werk (C 175) en Zeevaartpersoneel (C 186), en niet de verdragen over Visserijpersoneel (C 188) en Veiligheid en gezondheid in de landbouw (C 184).

Een interessante vraag is ook of een geratificeerd ILO-verdrag in Nederland directe (rechtstreekse) werking heeft en nationale wetgeving of beleid opzij kan zetten wegens strijd met een geratificeerd internationaal verdrag. ${ }^{8}$ Doorgaans is dat niet het geval, de ILO verdragen zijn meestentijds gericht aan de nationale overheid en zijn niet geformuleerd als individuele rechten. Bovendien stelt de Nederlandse rechter hoge eisen aan dergelijke rechtstreekse werking. Dat vindt zijn grond in het gegeven dat de rechter niet graag op de stoel van de wetgever plaatsneemt, nu de laatste volgens ons beperkt monistisch systeem bij ratificatie moet afwegen welke wijzigingen in de nationale wet vereist zijn om goede doorwerking van een verdrag in de Nederlandse rechtsorde te verzekeren. Het 'beroemdste' geval van rechtstreekse werking van een internationaal verdrag in het Nederlandse arbeidsrecht is de uitspraak van de Hoge Raad uit 1986 (NSarrest) inzake het stakingsrecht gebaseerd op artikel 6 lid 4 van het Europees Sociaal Handvest (ESH). In paragraaf 6 ga ik hier nader op in.

Onlangs (2017) nog heeft de Centrale Raad van Beroep (CRvB) rechtstreekse werking toegekend aan een bepaling in het VN Vrouwenrechtenverdrag, waardoor ook vrouwelijke zzp'ers recht hebben op een zwangerschaps- en bevallingsuitkering. Ook dit bespreek ik verder in paragraaf 6. Eerder, op 29 mei 1996, kende dit rechtscollege directe werking toe aan ILO-verdrag 102 inzake sociale zekerheid. Toen ging het over het ziekenfonds en een vergoeding van ziekenhuisopname bij bevalling.

Maar het blijft uitzonderlijk dat dergelijke directe doorwerking met afdwingbare rechten voor werkenden zich voordoet.

6 Zie hierover: Decent work op de agenda: Nederland en de normen van de Internationale Arbeidsorganisatie, Den Haag: Ministerie van Sociale Zekerheid en Werkgelegenheid 2008, p. 24.

7 www.ilo.org/dyn/normlex/en/f?p=1000:11001 en www.nidi.nl/nl/demos/2017/07/03.

8 Artikelen 93 en 94 Grondwet. 
Nederland heeft dus, al met al, een goede staat van dienst als het om ratificaties gaat. Nog wel opvallend is dat bijvoorbeeld het verdrag over ontslagbescherming van werknemers (C 158) niet is geratificeerd. Hierop kom ik in paragraaf 4 terug.

\section{Het ILO-supervisiesysteem}

Behalve het vaststellen van verdragen is de ILO ook actief in het houden van toezicht op de implementatie van de geratificeerde verdragen. Dat toezicht heeft enige byzantijnse trekken, in die zin dat het voor buitenstaanders niet altijd gemakkelijk te volgen is, niet transparant is en 'vele wegen naar Rome' kent. Er zijn nogal wat procedures mogelijk, die elkaar soms ook kruisen. ${ }^{9}$ Zie daarover ook mijn recente artikel in het Tijdschrift Recht en Arbeid. ${ }^{10}$

Hoofdroute van toezicht is de regelmatige rapportage aan de ILO door de lidstaten over implementatie van door hen geratificeerde verdragen en de controle daarop door de Committee of Experts (CoE). De rapportage van de lidstaten wordt voordat ze naar de ILO wordt gestuurd eerst nog voorgelegd aan de nationale sociale partners, die er ook hun, ze nodig kritische, commentaar bij kunnen schrijven. De CoE komt ieder jaar in november twee of drie weken naar Genève om de landenrapportages te onderzoeken en er een oordeel over te geven. Dat leidt jaarlijks in februari/maart tot een stevig rapport, met daarin aanbevelingen aan landen die in de ogen van de CoE niet of niet helemaal aan hun verplichtingen voldaan hebben. Vervolgens wordt het rapport van de CoE besproken in de Committee on Application of Standards (CAS), een vast comité van de jaarlijkse ILC. In de CAS wordt doorgaans een lijst van landen behandeld die blijkens het rapport van de CoE extra aandacht behoeven, in de wandelgangen ook wel de 'zwarte lijst' genoemd. Daar staat een lidstaat liever niet op. Nederland heeft in de laatste 25 jaar niet op die lijst gestaan.

De CAS komt uiteindelijk met aanbevelingen aan de lidstaat om de geconstateerde feilen te verhelpen. En vervolgens wordt, een jaar later, nagegaan of de aanbevelingen ook daadwerkelijk zijn opgevolgd. ${ }^{11}$

De ILO probeert via dit systeem naleving van geratificeerde verdragen te bereiken door dialoog en overtuigingskracht. Ook de druk van de internationale gemeenschap die de ILO is, kan - soms gepaard met media-aandacht - nog wel eens succesvol zijn.

Naast de hoofdroute van (1) rapportage door een lidstaat (2) CoE , (3) CAS en (4) controle op de uitvoering van de aanbevelingen zijn er ook bijzondere procedures.

9 Zie daarover ook het rapport aan de Governing Body van de ILO: A.G. Koroma \& P.F. van der Heijden, Review of ILO Supervisory Mechanism, ILO-GB, ILO 2016, www.ilo.org/wcmsp5/ groups/public/---ed_norm/---relconf/documents/meetingdocument/wcms_456451.pdf.

10 P.F. van der Heijden, De ILO: struikelend op weg naar de 100, TRA 2017/36, p. 3 e.v.

11 De laatste keer dat Nederland besproken is door de CAS was in 2004 betreffende de uitkering van salaris gedurende zwangerschapsverlof voor vrouwen; zie hiervoor www.ilo.org/dyn/ normlex/en/f?p=1000:13100:0::NO:13100:P13100_COMMENT_ID,P11110_COUNTRY_

ID,P11110_COUNTRY_NAME,P11110_COMMENT_YEAR:2556034,102768,Netherlands,2004. 
Is er in een lidstaat een probleem met vakbondsvrijheid ( $C$ 87) of collectieve onderhandelingsvrijheid (C 98), dan kan een klacht worden ingediend bij een speciale commissie, de Committee on Freedom of Association (CFA). Deze commissie komt drie keer per jaar bijeen in Genève om ingediende klachten te behandelen. De CFA is een vaste commissie van de Governing Body (GB), de Raad van Beheer van de ILO. Klachten kunnen worden ingediend door vakorganisaties en werkgeversorganisaties, niet door individuele personen. Klachten kunnen ook worden ingediend tegen lidstaten die de betreffende verdragen niet hebben geratificeerd, zoals bijvoorbeeld China en de VS. En dat gebeurt ook in de praktijk. ${ }^{12}$ Dat kan omdat vakbondsvrijheid tot de kern van de ILO behoort; twee derde van de 'macht' in de ILO behoort immers aan de werkgevers- en werknemersorganisaties, die zonder organisatievrijheid niet kunnen bestaan. De klacht kan leiden tot een aanbeveling van de ILO aan de betrokken lidstaat om de nationale praktijk en/of wetgeving te wijzigen. Ook tegen Nederland zijn wel klachten ingediend bij de CFA (zie paragraaf 5).

Naast de hoofdroute en de CFA-route bestaan nog twee vermeldenswaardige onderdelen van het supervisiesysteem.

Dat zijn de procedures zoals beschreven in de artikelen 24 en 26 van de ILO Constitutie. ${ }^{13}$

Eerst 'de artikel 24-procedure'. Hier kan een vakorganisatie of werkgeversorganisatie een klacht indienen over een specifiek onderwerp gerelateerd aan een geratificeerd verdrag. Er wordt dan een ad hoc tripartiete commissie benoemd, die de klacht behandelt. Ook tegen Nederland zijn wel klachten op deze basis ingediend door de FNV. Zie hierover paragraaf 7.

Ten slotte is er de 'artikel 26-procedure', die als de meest zware wordt gezien en slechts in uiterste gevallen wordt ingezet, zoals bijvoorbeeld tegen Myanmar of Qatar. ${ }^{14}$ Hier kan de ene lidstaat een klacht indienen tegen de andere lidstaat bij grove schending van de verplichtingen. Tegen Nederland is zo'n klacht nog nimmer ingediend.

\section{De ILO en de lonen in Nederland}

De ILO heeft in de vorige eeuw grote impact gehad op onze Wet op de loonvorming (Wet LV) en op bemoeienis van de overheid met de lonen, vooral in de semipublieke sector, zoals zorg en welzijn. ${ }^{15}$ Maar ook in de private sector werd van

12 Zie bijvoorbeeld recent een klacht tegen China: CFA, case nr. 3184, CFA, report nov. 2016, ook te lezen in: International Labor Rights Case Law Journal (ILaRC) 2017/2, p. 151 e.v., met noot van prof. Alan Neal (zie voor dit tijdschrift ook digitaal: www.brill.com/ilarc).

13 Zie voor de ILO Constitutie: www.ilo.org/dyn/normlex/en/f?p=1000:62:0::NO:62:P62_LIST_ ENTRIE_ID:2453907:NO.

14 Zie voor deze zaken: www.ilo.org/public/english/standards/relm/gb/docs/gb273/myanmar3. htm\#11. Legislation of Myanmar en www.ilo.org/dyn/normlex/en/f?p=1000:50010:0::NO:50010: P50010_ARTICLE_NO,P50010_DISPLAY_BY,P50010_COUNTRY_ID:26,2,103429.

15 Zie voor de wetten met de mysterieuze afkortingen TWACS en WAGGS: Stb. 1979, 346 en Stb. $1985,695$. 
tijd tot tijd wel met een 'bevriezing' van de lonen gedreigd, bijvoorbeeld in 1993 door minister van SZW Bert de Vries. ${ }^{16}$

De Wet LV gaf oorspronkelijk aan de minister van SZW grote bevoegdheden om in te grijpen in de cao-lonen. Hij kon ze onder omstandigheden bevriezen, en zelfs verlagen. Ook was er een periode waarin voorafgaande goedkeuring van cao's door de minister verplicht was. Tot aan de jaren zeventig van de twintigste eeuw kenden we in ons land de 'geleide loonpolitiek', die aan de overheid een grote rol toedichtte, in samenspraak met de sociale partners. Dat leidde in die periode niet tot klachten bij de ILO, omdat de sociale partners zich erin konden vinden. In de jaren zeventig en tachtig werd de geleide loonpolitiek verlaten, werden de bonden radicaler ('centen in plaats van procenten') en kwam Nederland fors in aanvaring met de ILO.

In het systeem van arbeidsvoorwaardenvorming zoals dat is vastgelegd in ILOverdragen 87 en 98 zijn alleen de sociale partners en is juist niet de overheid verantwoordelijk voor de lonen. Vakbonden en werkgevers(organisaties) sluiten cao's af, waarin onder meer dit uiterst belangrijke onderwerp wordt geregeld. De regelingsmacht van de overheid is hier beperkt. De overheid mag zich 'slechts' bezighouden met het leggen van een bodem in de onderhandelingen tussen de sociale partners door wettelijk een minimumloon of een plafond in de vorm van een maximumloon vast te stellen, zoals is gebeurd in de Wet normering topinkomens en de Bonuswet voor de banken. Alles daartussen is het terrein van vakbonden en werkgevers, die in alle vrijheid moeten kunnen opereren.

In de jaren tachtig en negentig werden door de overheid vele koppelingen aangebracht in het inkomensvoorzieningssysteem. De lonen in de publieke en semipublieke sector en de sociale uitkeringen werden gekoppeld aan de loon stijgingen in de private sector. De overheid had dus groot belang bij de tempering van de loonhoogte in de private sector, omdat als gevolg van deze koppelingen de overheidsuitgaven sterk werden beïnvloed door de loonsverhogingen in de private sector. Daarom bevatte de Wet LV vergaande bevoegdheden voor de minister van SZW om de lonen in de private sector te bevriezen, tot verdriet en woede van de bonden. Na lang verzet door opeenvolgende kabinetten zijn uiteindelijk toch de Wet LV, de Tijdelijke wet arbeidsvoorwaarden collectieve sector (TWACS) en de Wet arbeidsvoorwaardenontwikkeling in de gepremieerde en gesubsidieerde sectoren (WAGGS) aangepast aan de ILO-eisen, gebaseerd op de geratificeerde ILOverdragen 87 en $98 .{ }^{17}$ Wie nu artikel 10 Wet LV leest, ziet dat het een artikel is waar lang en veel aan gesleuteld is. Dat gebeurde onder invloed van de ILO, die voor dit doel een speciale missie onder leiding van de Amerikaanse arbeidsrechtprofessor Windmuller naar Nederland had gezonden.

Naar huidig recht heeft de minister slechts in heel uitzonderlijke gevallen zoals oorlog of oliecrisis het recht om, uitsluitend tijdelijk, in te grijpen in de lonen.

16 Zie P.F. van der Heijden, Loonwet 1994: collectieve contractsvrijheid ingevroren, NJB 1993, p. 1133 e.v.

17 Zie Kamerstukken II, 23822, Stb. 1994. 958 en de in noot 18 genoemde literatuur. 
'Alleen' een economische crisis is niet voldoende om het artikel te kunnen gebruiken. ${ }^{18}$

In de afgelopen economische crisis (2008-2015) is niet in Nederland, maar wel in andere Europese landen door regeringen zonder overleg en dialoog met de sociale partners ingegrepen in de cao-lonen, bijvoorbeeld in Griekenland, Portugal en Spanje. Dat kwam ze allemaal op een schrobbering door de ILO te staan. ${ }^{19}$

\section{De ILO en vakbondsvrijheid/cao}

Er zijn in de periode van het bestaan van de CFA, nu zo'n 65 jaar, tien klachten ingediend bij die commissie tegen Nederland. Als we de zeven zaken uit de vorige eeuw buiten beschouwing laten, zijn er drie te noteren sinds 2000. In 2004 dienden de FNV/CNV/MHP een klacht in (CFA, case nr. 2379), die later lopende de rit is ingetrokken. ${ }^{20}$ In 2008 werd een klacht ingediend over het Toetsingskader Algemeen Verbindend Verklaren (AVV) van Cao-bepalingen (CFA, case nr. 2628). De klacht werd in gediend door Altro Via, een werkgeversvereniging, tezamen met LBV, een werknemersvereniging, die beide als nieuwe en kleine actoren in de transportsector een cao hadden gesloten. Deze cao werd 'overruled' door de verbindendverklaring van een andere 'grotere' cao met de bekende bonden en werkgeversorganisaties. Altro Via en LBV meenden dat het Toetsingskader AVV in strijd was met ILO-verdrag 87, omdat nieuwe en kleine werkgevers- of werknemersverenigingen in de sector hierdoor niet in vrijheid konden onderhandelen. De CFA constateerde dat de regeling niet in strijd was met de vakbondsvrijheid, zoals ook minister Donner van SZW in zijn verweer had betoogd. Het verbindend verklaren van een cao voor niet-vakbondsleden van partijen bij de cao is mogelijk zolang de wet garandeert dat de meest representatieve organisaties van werknemers namens de laatsten onderhandelen. ${ }^{21}$

In 2011 is een klacht ingediend door de werkgeversvereniging Post Nederland. Zij was van oordeel dat de Nederlandse overheid haar dwong tot het overeenkomen van een cao met een bepaalde inhoud en tot bemiddeling door een in haar ogen partijdige bemiddelaar, in de persoon van $\mathrm{dr}$. Ruud Vreeman, oud-FNV-vakbondsman en oud-PvdA-voorzitter. Een en ander speelde zich af in de context van de liberalisering van de postmarkt en de sociale condities waaronder die moest plaatsvinden. Volgens de CFA was er wat betreft de 'gedwongen' totstandkoming

18 Zie verder hierover uitgebreid de dissertaties van K. Boonstra, The ILO and the Netherlands (diss. Leiden), NJCM Boekerij 1996, en W.G.M. Plessen, Collectief onderhandelen in de zorgsector (diss. Tilburg), Deventer: Kluwer 1996.

19 Zie bijvoorbeeld dit onderzoek van de ILO: www.ilo.org/global/about-the-ilo/newsroom/news/ WCMS_415612/lang--en/index.htm.

20 De inhoud van de klacht is helaas niet meer te achterhalen. www.ilo.org/dyn/normlex/en/f?p= 1000:50001:0::NO:50001:P50001_COMPLAINT_FILE_ID:2897175.

21 www.ilo.org/dyn/normlex/en/f?p=1000:50002:0::NO:50002:P50002_COMPLAINT_TEXT_ID: 2911309. 
van de cao geen strijd met ILO-verdrag 87/98, maar was de benoeming van een bemiddelaar die niet het vertrouwen had van een van de partijen wel laakbaar. ${ }^{22}$ We zien dus twee klachten, die zijn ingediend door partijen die niet bij het gebruikelijke 'circuit' horen, geen steun krijgen in de Nederlandse polder en politiek, 'miskend worden' in de nationale context en hun heil buiten Nederland zoeken. Een verschijnsel dat dikwijls te zien is bij een beroep op een internationaal verdrag waar Nederland aan gebonden is.

\section{De ILO en het stakingsrecht}

In Nederland kennen we geen nationale stakingswet of een artikel in de Grondwet hierover, zoals in veel andere landen wel het geval is. Stakingsrecht is in Nederland rechtersrecht, waarbij de Hoge Raad zich sinds 1986 bij gebrek aan nationale wetgeving baseert op artikel 6 lid 4 ESH. ${ }^{23}$

In landen buiten Europa waar het stakingsrecht ook niet wettelijk is geregeld, kan de ILO de rol vervullen die het ESH bij ons speelde (en nog steeds speelt). De ILO kent geen apart verdrag over het stakingsrecht; het recht wordt beschouwd als geïncludeerd in ILO-verdrag 87. Vakverenigingsvrijheid en stakingsrecht horen bij elkaar als een Siamese tweeling; het een kan niet zonder het ander. In de onderhandelingen die vakbonden voeren over arbeidsvoorwaarden kan dit uiterste machtsmiddel niet ontbreken. Zonder dat is de bond uiteindelijk tandeloos en machteloos. Daarbij wordt overigens erkend dat het stakingsrecht begrenzingen en beperkingen kent, die uiteraard ook zijn terug te vinden in de uitleg van ILOverdrag 87 door de $\mathrm{CoE}$ en de CFA. ${ }^{24}$

Behalve het ESH kan de Nederlandse rechter ook het door Nederland geratificeerde ILO-verdrag 87 en de uitleg daarvan gebruiken in de beoordeling van stakingen. Belangrijk daarbij is te onderkennen dat het ILO-stakingsrecht betrekking heeft op 'workers', een begrip dat ruimer is dan 'werknemers' en bijvoorbeeld ook zzp'ers kan omvatten. Zie daarover het slot van deze paragraaf.

Vanaf 2012 hebben de werkgevers in de ILO serieuze pogingen ondernomen de ILO-stakingsdoctrine, zoals die tot dan toe gold, te ontmantelen. De werkgevers namen toen, tot ieders verrassing, in de CAS het standpunt in dat het recht van staking niet is terug te vinden in ILO-verdrag 87, dat het recht 'slechts' een interpretatie is van dat verdrag door de CoE, en dat zij die interpretatie niet (meer) delen. ${ }^{25}$ Sindsdien zijn de verhoudingen in de ILO tussen werkgevers en werkne-

22 Zie over deze episode in het 'liberalisering van de post'-epos: G.A. Stouthart, Een paradox: liberalisering van de postmarkt leidt tot regulering van de arbeidsverhoudingen, TRA 2010/5, p. 201-206.

23 HR 30 mei 1986, NJ 1986/688, m.nt. PAS. Zie ook L.A.J. Schut, Internationale normen in het Nederlandse stakingsrecht (diss. Leiden), Den Haag: Sdu 1996.

24 Zie over het ILO-stakingsrecht hoofdstuk 10 van de Digest of decisions and principles of the CFA, een (ook digitaal beschikbaar) ILO-boek met een compilatie van de belangrijkste uitspraken van de CFA sinds haar ontstaan in 1952: www.ilo.org/global/standards/information-resourcesand-publications/publications/WCMS_090632/lang--en/index.htm.

25 www.ilo.org/wcmsp5/groups/public/---ed_norm/---normes/documents/publication/wcms_ 190828.pdf. 
mers ernstig verstoord en verziekt geraakt. Tot de dag van vandaag geeft de CAS als gevolg van het werkgeversstandpunt geen oordelen meer over stakingskwesties, en het overleg tussen werkgevers en werknemers gaat over tal van punten die aan dit onderwerp raken zeer moeizaam. In een poging uit de impasse te komen hebben de werkgevers- en werknemersgeleding in de ILO in 2015 een zogeheten 'joint statement' uitgebracht over de kwestie waarbij over en weer het recht op collectieve actie werd erkend: voor de werkgevers het recht op uitsluiting, voor de werknemers het recht op staking. ${ }^{26}$

Deze verklaring heeft sindsdien wel als een soort wapenstilstand tussen de kemphanen gefunctioneerd, maar het probleem is daarmee niet weg.

De meest voor de hand liggende echte oplossing voor deze kwestie is om artikel 37 van de ILO Constitutie te volgen. ${ }^{27}$ Dat voorziet in twee mogelijkheden in geval van een interpretatieprobleem van een ILO-verdrag: ofwel de kwestie voorleggen aan het Internationale Hof van Justitie in Den Haag, ofwel een ad hoc tribunaal benoemen dat de kwestie beslecht. Met beide mogelijkheden wilde en wil de werkgeversgeleding in de ILO tot op heden niet akkoord gaan, waardoor het conflict zich nu al jaren voortsleept zonder uitzicht op een oplossing. Helaas moeten we vaststellen dat het Nederlandse VNO-NCW zich nergens in deze discussie zichtbaar en strijdbaar heeft getoond voor de al sinds jaar en dag geaccepteerde uitleg van ILO-verdrag 87 en het collectieve actierecht van de vakbeweging, net zo min als de Nederlandse regering dat heeft gedaan. Verdrag 87 is een kernverdrag van de ILO, het behoort tot de pijlers van de hele organisatie, het behoort tot de fundamentele arbeidsrechten van de ILO. Verwacht had mogen worden dat, om uit de impasse te komen, behalve de vakorganisaties ook de Nederlandse regering en VNO-NCW zich sterk hadden gemaakt voor een gang naar het Internationale Hof van Justitie in Den Haag.

Ik kom terug op de zzp'ers en het stakingsrecht. In 2016 deden zich acties voor bij de postpakketbezorgers van Post NL. Dat zijn dikwijls zzp'ers, die zich hebben georganiseerd in de Vereniging Subco Partners. Er bestond grote onvrede over de wijze waarop zij hun werk moeten verrichten en de beloning die zij ontvangen. De acties liepen uit op blokkering van een depot van Post NL. Blokkade is nooit toegestaan als vorm van collectieve actie, ook niet onder artikel 6 lid 4 ESH, en die actie werd dus begrijpelijkerwijze door de rechter verboden. ${ }^{28}$ In mijn noot onder dit vonnis vraag ik er aandacht voor dat volgens uitspraken van de CFA ook 'selfemployed workers' onder de bescherming van ILO-verdrag 87 vallen en zich ook op het stakingsrecht en collectieve actierecht van de ILO kunnen beroepen. ${ }^{29}$

26 Zie www.ilo.org/gb/events/WCMS_346764/lang--en/index.htm.

27 Zie voor het genoemde artikel: www.ilo.org/dyn/normlex/en/f?p=1000:62:0::NO:62:P62_LIST_ ENTRIE_ID:2453907:NO.

28 Rb. Utrecht 20 juli 2015, JAR 2015/202.

29 Voor de noot zie: P.F. van der Heijden (red.), JAR 25 jaar: een hooggeleerde selectie met annotaties verfraaid, Den Haag: Sdu Uitgevers 2016, p. 565-570. 


\section{$7 \quad$ De ILO en de Arbeidsinspectie}

Een van de zaken die de FNV samen met de CNV en de VCP (voormalige MHP) recent (in 2013/2014) bij de ILO tegen Nederland heeft aangekaart, betrof, onder meer, de omvang van en de werkdruk bij de Nederlandse Arbeidsinspectie. De klacht werd ingediend op verzoek van de ondernemingsraad van de Arbeidsinspectie, die zelf geen procedures bij de ILO kan beginnen. Het gaat hier om de ILO-verdragen 81 en 155. De FNV, CNV en VCP maakten gebruik van de procedure volgens artikel 24 ILO Constitutie (zie paragraaf 3 ) en klaagden over het gebrek aan voldoende arbeidsinspecteurs, onvoldoende tijd voor scholing en een onaanvaardbare werkdruk, en dus over schending van de verplichtingen voortvloeiend uit de geratificeerde ILO-verdragen 81 en 155. Een en ander speelde in de tijd van grote overheidsbezuinigingen, die ook gevolgen had voor het personeelsaantal en de opleidingen van de Arbeidsinspectie.

Zoals gebruikelijk in deze procedure werd door de GB van de ILO een ad hoc tripartite commissie ingesteld, die de klacht intensief heeft onderzocht. Zij begon uiteraard eerst met het vragen naar de reactie van de Nederlandse regering op de ingediende klachten. Die reactie kwam en probeerde aan te tonen dat er niets aan de hand was. En daar was de ingestelde ILO-klachtencommissie het weer niet helemaal mee eens. In de conclusies van de zaak, die altijd in de vorm zijn gegoten van aanbevelingen aan de lidstaat, riep de ILO de Nederlandse regering op inderdaad wat aan de klachten met betrekking tot het aantal inspecties en dus inspecteurs te doen en ook te zorgen dat deze functionarissen voldoende getraind zijn. De klacht van de vakbonden was dus (gedeeltelijk) gegrond en er was zeker spanning tussen de praktijk in Nederland en de verplichtingen die uit de ILO-verdragen 81 en 155 volgen. De GB van de ILO verwees de zaak verder naar de CoE om de follow-up in de gaten te houden. ${ }^{30}$ Blijkens Rapport 2016 van de CoE was het varkentje nog niet gewassen in dat jaar en werden verdere vragen gesteld aan de Nederlandse regering.

De vraag kan worden opgeworpen of deze ingewikkelde weg langs de ILO-procedures kan worden vermeden en er direct bij de Nederlandse rechter een voorziening kan worden gevraagd en verkregen. Had bijvoorbeeld de ondernemingsraad van de Arbeidsinspectie bij de Nederlandse rechter een voorlopige voorziening kunnen vragen over het tekort aan inspecteurs, met een beroep op artikel 10 van ILO-verdrag 81, dat Nederland heeft geratificeerd?

We komen dan terecht in het al eerder genoemde leerstuk van de doorwerking en rechtstreekse of directe werking van internationale verdragen in de Nederlandse rechtsorde. ${ }^{31}$ Soms lastig te beantwoorden vragen, omdat de rechter dan moet uitmaken of een verdragsbepaling de bedoeling heeft om rechtstreeks te werken, afgaand op de redactie en bewoordingen ervan. Zoals hiervoor al opgemerkt, kende de Hoge Raad in 1986 rechtstreekse en directe werking toe aan artikel 6 
lid 4 ESH omtrent het recht op collectieve actie van werknemers bij de NS. ${ }^{32}$ En oordeelde de CRvB onlangs dat het VN Vrouwenverdrag direct werkt in Nederland, waardoor vrouwelijke zzp'ers recht hebben op dezelfde zwangerschapsuitkering als werkneemsters. ${ }^{33}$

Het ligt niet voor de hand dat artikel 10 van ILO-verdrag 81 directe werking toegekend zal worden. Het artikel is niet voldoende nauwkeurig om zonder meer als objectief recht te kunnen worden toegepast.

De beoordeling van de vraag of een ILO-verdragsartikel directe werking heeft, verliep sinds het NS-stakingsarrest van 1986 in drie en sinds het Rookverbodarrest van de Hoge Raad (HR 10 oktober 2014) in twee stappen. De twee stappen zijn: (1) indien uit de tekst en uit de totstandkomingsgeschiedenis van het verdrag niet volgt dat de verdragsbepaling in kwestie geen rechtstreekse werking krijgt, is haar inhoud beslissend; en (2) het verdragsartikel is eenieder verbindend als het onvoorwaardelijk en voldoende nauwkeurig is om in de nationale rechtsorde zonder meer als objectief recht te worden toegepast. ${ }^{34}$

Deze Rookverbod-leer van de Hoge Raad paste de CRvB in 2017 weer toe in het eerder in paragraaf 2 genoemde geval van de zwangerschapsuitkering voor zzp'ers.

\section{De ILO en het ontslagrecht}

Nederland heeft ILO-verdrag 158 uit 1982 over het ontslagrecht (dat wil zeggen beëindiging door de werkgever) niet geratificeerd, maar stemde wel vóór de totstandkoming van dit verdrag op de ILC in $1982 .{ }^{35}$ De gerechtvaardigde vraag luidt dan ook waarom $C 158$ eigenlijk niet is geratificeerd.

Wat is de kern van ILO-verdrag 158? Die is te vinden in de artikelen 4, 5, 6 en 7.36 Er moet een geldige reden ('valid reason') voor het ontslag door de werkgever zijn, verband houdend met de capaciteit of het gedrag van de werknemer, of het ontslag moet gebaseerd zijn op de operationele activiteiten van de werkgever. In de artikelen 5 en 6 wordt een aantal ontslagverboden geformuleerd, en in artikel 7 wordt gestipuleerd dat een werknemer door de werkgever moet worden gehoord alvorens ontslag wordt aangezegd.

In de jaren negentig van de vorige eeuw is er contact geweest tussen de toenmalige minister van SZW en het bureau van de ILO over mogelijke ratificatie door Nederland. Dat zou betekenen dat het toenmalige Nederlands ontslagrecht, dat geen wettelijke 'valid reason'-bepaling kende, zou moeten worden gewijzigd. Zoals bekend is dat toen niet gebeurd.

32 Spoorwegstakingsarrest: HR 30 mei 1986, NJ 1986/68, m.nt. PAS.

33 ECLI:NL:CRVB:2017:2461.

34 Zie hierover uitgebreid: R.J.B. Schutgens, Het rookverbod en de bevoegdheid van de Hoge Raad om wetgeving aan verdragen te toetsen, Ars Aequi april 2015, p. 305 e.v.

35 Tractatenblad 1984-17.

36 Zie voor C 158: www.ilo.org/dyn/normlex/en/f?p=NORMLEXPUB:12100:0::NO::P12100_ILO_ CODE:C158. 
Wel had later de in 2000 acterende Adviescommissie Duaal Ontslagstelsel (ook wel de commissie-Rood genoemd, naar haar voorzitter: prof. mr. Max Rood) van de minister de opdracht meegekregen in een nieuw te ontwerpen ontslagrecht ook ILO-verdrag 158 te betrekken, en dat heeft ze ook gedaan. De commissieRood kwam met twee voorstellen, één voor een preventief en één voor een repressief ontslagrecht, beide met aanwijzingen voor de implementatie van C 158 . De commissie had zelf een voorkeur voor het repressieve stelsel, waarin voorzien werd in het ILO-vereiste van een wettelijk vastgelegde geldige reden voor ontslag. De commissie-Rood voorzag in haar voorstellen ter zake ook in de 'hoorplicht' van de werkgever. ${ }^{37}$

Ook de voorstellen van de commissie-Rood zijn op niets uitgelopen.

Bij de totstandkoming van het huidige ontslagrecht van de Wet werk en zekerheid (Wwz) in 2014 heeft ILO-verdrag 158 geen grote rol gespeeld. Was bij het 'oude' ontslagrecht het ontbreken van een wettelijk voorschrift omtrent de geldige reden voor ontslag een belangrijk obstakel voor ratificatie, dan is die reden nu vervallen. Artikel 7:669 van het Burgerlijk Wetboek (redelijke grond) voorziet hier thans immers in.

Wel is er nog steeds de eis van hoorplicht van de werkgever voorafgaand aan een ontslag, waarin ILO-verdrag 158 voorziet en ons ontslagrecht niet. (Het ambtenarenontslagrecht voorziet er vanwege de Algemene wet bestuursrecht weer wel in, maar dat loopt af in 2020 als de Normalisatiewet in werking treedt en ook voor ambtenaren de Wwz gaat gelden.)

Ratificatie van ILO-verdrag 158 is dan ook in de nabije toekomst niet te verwachten, hoewel er wel een nieuwe kans ligt nu de Wwz en het ontslagrecht door het kabinet-Rutte III weer gewijzigd gaan worden.

\section{De ILO en MVO}

Maatschappelijk Verantwoord Ondernemen (MVO) is in Nederland een belangrijk onderwerp, ook voor juristen. ${ }^{38}$ De overheid in de persoon van de minister van Handel, die fundamentele arbeidsrechten in handelsverdragen opgenomen wil zien, de Sociaal-Economische Raad (SER) met zijn werkgroep Internationaal Maatschappelijk Verantwoord Ondernemen (IMVO) en de daar gesloten convenanten voor de textiel-, de banken- en de goudsector, waarin ook weer naar fundamentele arbeidsrechten van de ILO wordt verwezen, het lidmaatschap van de Organisatie voor Economische Samenwerking en Ontwikkeling (OESO) en de OESO-gedragscode voor multinationals, en de aanwezigheid van veel hoofdkanto-

37 Zie p. 75 e.v. en 103 e.v. in het rapport: www.estibbe.com/nieuwontslagrecht/documenten/ Advies\%20afscheid\%20van\%20het\%20duale\%20ontslagrecht\%2015\%20november\%202000. pdf. Zie ook hierover: G. van Arkel, A just cause for dismissal in the US and the Netherlands (diss. Erasmus Universiteit), Rotterdam 2007.

38 Zie bijvoorbeeld dit preadvies voor de NJV in 2010: http://njv.nl/samenvatting-preadvies-2010eijsbouts-kristen-de-jongh-schild-timmerman-maatschappelijk-verantwoord-ondernemen-naastin-of-met-recht/. 
ren van multinationals (Philips, Heineken , AkzoNobel, Shell, Unilever enzovoort), die deze OESO-code hebben ondertekend, ondersteunen deze stelling. De ILO heeft zelf ook al lang, sinds 1977, een gedragscode voor multinationals, die onlangs nog is geactualiseerd. ${ }^{39}$ Deze 'Declaration' speelt tot op heden geen belangrijke rol, vermoedelijk vanwege de moeilijke leesbaarheid ervan (lang en wollig) en vooral vanwege het ontbreken van een geschillenmechanisme.

In de genoemde SER-IMVO-convenanten en de OESO-gedragscode wordt onder (veel) meer met name verwezen naar de zogenoemde 'core labour standards' van de ILO. ${ }^{40}$ In 1998 heeft de ILO de 'Declaration on Fundamental Principles and Rights at Work' vastgesteld. ${ }^{41}$ Hierin worden vier belangrijke thema's aangeduid, die zijn terug te voeren tot acht ILO-verdragen, die allemaal door Nederland zijn geratificeerd. Het gaat om vrijheid van organisatie en collectieve onderhandelingen, en verbod van kinderarbeid, dwangarbeid en discriminatie op de werkplek. ${ }^{42}$ De aan de OESO-gedragscode en/of aan de SER-IMVO-convenanten van de SER gebonden bedrijven hebben zich, door zich aan te sluiten bij deze codes, ook verbonden om de 'core labour standards' van de ILO te respecteren. Hoewel wij ons hier in het gebied van de 'soft law' bevinden, heeft de ondertekening van de code(s) ook juridische consequenties.

De OESO-gedragscode en het SER-IMVO-convenant voor de textielsector kennen, anders dan de ILO-gedragscode, geschillenregelingen waar klachten kunnen worden ingediend. ${ }^{43}$ De OESO kent bijvoorbeeld de National Contact Points (NCP's), waarvan er ook één in Den Haag is gevestigd. ${ }^{44}$ Het NCP is geen arbitrage of rechterlijk instituut, maar probeert door mediation tot een oplossing van een aangebracht geschil te komen. Zo is bijvoorbeeld recent een succesvolle mediation afgesloten in een zaak tussen Heineken en een aantal ex-werknemers van een dochteronderneming van Heineken in Congo, Afrika. ${ }^{45}$ Het ging om een vergoeding voor onterecht gegeven ontslag.

Mocht een mediation niet slagen, dan staat soms de weg open naar de civiele rechter, die moet beoordelen of schending van de ondertekende code een onrechtmatige daad oplevert die tot schadevergoeding leidt. ${ }^{46}$ De rechter is dan

www.ilo.org/empent/Publications/WCMS_094386/lang--en/index.htm.

40 Zie voor de SER-IMVO-convenanten: www.ser.nl/nl/themas/imvo.aspx; zie voor de OESO-richtlijnen: www.oesorichtlijnen.nl/oeso-richtlijnen/o/oeso-richtlijnen.

41 www.ilo.org/declaration/lang--en/index.htm.

42 Te vinden in de ILO-verdragen 87, 98, 29, 105, 138, 182, 100 en 111.

43 P.F. van der Heijden, Uitbreiding van handhavingsmechanismen fundamentele arbeidsrechten. Is meer ook beter?, NJB 2014/12, p. 768-775. Zie ook: R. Zandvliet \& P.F. van der Heijden, The rapprochement of ILO standards and CSR mechanisms: towards a positive understanding of the 'privatization' of international labour standards, in: A. Marx e.a., Global Governance of Labour Rights, Edward Elgar Publishing 2015, p. 170 e.v.

44 www.oesorichtlijnen.nl/ncp.

45 www.oesorichtlijnen.nl/actueel/nieuws/2017/08/18/eindverklaring-melding-voormaligewerknemers-bralima-\%E2\%80\%93-bralima-en-heineken.

46 Zie hierover het rapport 'De juridische verantwoordelijkheid van Nederlandse moederbedrijven voor de betrokkenheid van dochters bij schendingen van fundamentele, internationaal erkende rechten' van prof. dr. A.G. Castermans en dr. J.A. van der Weide, www.parlementairemonitor.nl/ 9353000/1/j9vvij5epmj1ey0/vibl8vaz64zp. 
mogelijk ook gehouden te komen tot uitleg of interpretatie van de betreffende ILO-verdragen, en kan daarbij terugvallen op de door de ILO-supervisie-instanties zoals de $\mathrm{CoE}$ en de CFA eerder gegeven interpretatie en uitleg. Zo kan soft law uitgroeien tot hard law, waarbij de geratificeerde ILO-verdragen en hun uitleg van groot belang zijn.

\section{Slot}

Nederland is vanaf het prille begin in 1919 lid van de ILO. In deze bijdrage is gebleken dat dit lidmaatschap belangrijke consequenties had, heeft en houdt voor het Nederlandse arbeidsrecht. Nederland heeft zich doorgaans opgesteld als een actief en betrokken lid. Het heeft in vergelijking met veel andere lidstaten relatief veel verdragen geratificeerd en geïmplementeerd in zijn nationale rechtsorde. Ook voldoet het aan de rapportageverplichtingen aangaande de geratificeerde verdragen.

Opvallend is dat Nederland ILO-verdrag 158 over het ontslagrecht niet heeft geratificeerd. Dat zou bij de komende herziening van het ontslagrecht door het kabinet-Rutte III alsnog kunnen veranderen. Dan zal wel wettelijk moeten worden voorzien in een hoorplicht van de werkgever, voorafgaand aan het ontslag van de werknemer.

Helaas wordt er door Nederland niet altijd ferm opgetreden als er belangrijke zaken in de ILO zelf aan de orde zijn. Zo waren de Nederlandse regering en 'ons' VNO-NCW niet erg zichtbaar actief in de moeizame en sfeerbedervende discussie over de destructieve actie van de werkgeversgeleding in de ILO met betrekking tot het ILO-stakingsrecht, zoals die zich afspeelde tussen 2012 en heden. De kwestie zelf is door een 'wapenstilstand' in 2016 tot zekere rust gebracht, maar is nog steeds niet opgelost, zorgt nog steeds voor sfeerbederf en dus zijn er mogelijkheden tot herkansing hier.

Op terreinen waar veel overheidsgeld mee gemoeid is, zoals bijvoorbeeld de loonpolitiek, de sterkte van de Arbeidsinspectie of de sociale zekerheid, leeft de Nederlandse overheid pas na veel druk van de ILO en een lang tijdsverloop de aangegane verplichtingen na, en daar moet dan meestal een procedure bij het ILO-toezichtmechanisme of voor de nationale rechter aan te pas komen. ${ }^{47}$ Internationale verplichtingen mogen, zo lijkt het, zeker in tijden van bezuinigingen ook weer niet (te) veel kosten.

De ILO biedt met haar toezichtmechanisme een extra 'check' voor Nederlandse wetgeving of beleid op het gebied van arbeidsrecht. Met name de FNV en ook werkgevers- en werknemersbonden, die zich buiten het gebruikelijke 'poldercircuit' bevinden, weten de weg van de extra check goed te vinden. 
Het ziet er naar uit dat voornamelijk de 'core labour standards' van de ILO, ook wel de fundamentele arbeidsrechten genoemd, via de band van de soft law in internationale gedragscodes en convenanten in Nederland een steeds indringender juridische en harde(re) kant krijgen. Daarmee wordt er naast de aloude handhavingsmechanismen van het internationaal publiekrecht een nieuw, privaatrechtelijk, speelveld geopend voor Nederlandse arbeidsrechtjuristen. 